\title{
The Peculiarities of Conducting Special Operational-Search Measures in the Fight Against Crime
}

\author{
K.S. Madiev ${ }^{1, *}$, T.A. Koszhanov ${ }^{1}$, A.D. Shaimuhanov ${ }^{2}$ and V.V. Filin ${ }^{3}$ \\ ${ }^{1}$ Department of Operational Search Activity, Karaganda Academy of the Internal Affairs of the Republic of \\ Kazakhstan Named after Barimbek Beysenov, Karaganda, Republic of Kazakhstan \\ ${ }^{2}$ Economic and Legal Research, Karaganda Economic University of Kazpotrebsoyuz, Karaganda, The \\ Republic of Kazakhstan \\ ${ }^{3}$ Department of General Law and Special Disciplines, Karaganda Economic University of Kazpotrebsoyuz, \\ Karaganda, The Republic of Kazakhstan, Akademicheskaya str., 9;
}

\begin{abstract}
The relevance of the study is due to the need to determine the feasibility of using special operational-search measures in the system of operational-search activities of the authorized bodies of Kazakhstan and to establish their place and importance in the fight against crime.

In this regard, this article is aimed at identifying and disclosing the essence of operational search activities, identifying their main content. A comparative study of the legislation of individual countries providing for similar activities was carried out in order to identify the features of the conduct and the legal regulation of operational search activities and their significance.

As a result of the study, it was concluded that the features of special operational-search measures are manifested only in their number, name, and partly in the content of the actions taken, while their essence is manifested almost equally. Along with this, to ensure the reliability of the results obtained, scientific and technical means are being actively introduced, mechanisms and methods for recording operational information are being improved, and scientific knowledge is being accumulated and well-grounded recommendations for conducting operational-search measures.

The materials of the article are of practical value for the bodies that carry out operational investigative activities, scientific and practical workers of the authorized bodies.
\end{abstract}

Keywords: Special operational-search measures, operational-search activity, authorized state bodies, crime, security provision.

\section{INTRODUCTION}

At present, the historical and legal sciences cannot answer the question when the operational-search measures arose, who carried them out first and for what purposes.

With the emergence of the state, one of the functions was to ensure its interests, protect the territory, identify and counter external threats, as well as timely identify such threats (Vinnichenko, Zakharysev \& Rohlin, 2004). Along with the creation of the armed forces for defense, it was necessary to be able to establish a threat in advance, which became an early form of secret activities.

It is known that in ancient Egypt, work was carried out to identify and suppress popular uprisings. Thus, according to sources, information about upcoming insurrections and attempted coup, despite the conspiracy of the conspirators, were promptly delivered

*Address correspondence to this author at the Department of Operational Search Activity, Karaganda Academy of the Internal Affairs of the Republic of Kazakhstan Named after Barimbek Beysenov, Karaganda, Republic of Kazakhstan; E-mail: madevku@mail.ru to the Egyptian capital of Thebes. This indicates a welldeveloped system of informers and an established courier connection between the province and the center (Umnov, 2000).

In Tsarist Russia, which included the territories of Central Asia and Kazakhstan, the law "On the organization of the detective unit", adopted on July 6 , 1908, had a major role in the development of operational-search measures, which created the legal basis for criminal investigation in general.

In October 1920, the Central Criminal Investigation Department was established as a subdivision under the head police department of Kazakhstan. In all large cities of the republic criminal investigation departments were organized (Suetin, 2018).

It is clear that the history of the Kazakh militia, especially its activities in the first years of the existence of Soviet power, is unfortunately poorly studied. Mountains of materials stored in archives are still waiting for their researchers. And in such a closed area as an operational-search activity, very few traces remained. 
Meanwhile, it should be noted that with the development of the state, the formation of new social relations, the strengthening of state power, its organs were strengthened in the fight against crime. As in one of the reports in July 1925, the first people's commissar of internal affairs of the Kazakh Autonomous Soviet Socialist Republic Abdrakhman Aytiev noted, the main task was to strengthen the personnel potential. For which reason, the police and criminal investigation officers needed to study the issues of the protection of the revolutionary order, the personal safety of citizens and their property. To ensure the implementation of decrees, laws and regulations, the fight against various types of crimes (horse thief, moonshine, hooliganism) (Kaidarov \& Kul'baeva, 2016).

On September 15, 1994, the first Law on Operational Investigation Activities in the Republic of Kazakhstan (Sysalov, 2002) was adopted, which established a list of special operational-search measures. This law regulated not only the grounds and conditions for holding secret events, but also, and very importantly, established the procedure for using their results in proving criminal cases.

The objective conditionality of the formation of the theory of operational-search measures, as a private theory of operational-search activity, is caused by the increase in crime. It should be noted that in the Republic of Kazakhstan there is not a sufficiently high detection of criminal offenses.

\section{MATERIALS AND METHODS}

The leading method used in the study of this problem is a critical-legal analysis, which made it possible to comprehensively review the content of special operational-search measures and reveal the similarity of the legal regulation of the catalog of special operational-search measures provided for by the legislation of Kazakhstan and individual countries of the Commonwealth of Independent States and the Baltic States.

According to official statistics, in 2017, there were registered: 935 killings, detection rate - 91.3 percent; 680 robberies, detection rate - 79.5 percent; 9,450 robberies, disclosure - 55.6 percent; 192913 thefts, disclosure - 45 percent. In 2018, 255,375 crimes were recorded of them: 934 murders, detection rate - 89.9 percent; 579 robberies, detection rate - 79.9 percent; 8067 robberies, disclosure - 56.8 percent; 179719 thefts, disclosure -41.2 percent. For the 5 months of 2019, 97,950 crimes were recorded of them: 350 murders, detection rate - 88.7 percent; 262 robberies, disclosure - 83.2 percent; 2962 robberies, disclosure 63.9 percent; 63802 thefts, disclosure - 78.7 percent (Analytical information: Information on criminal offenses).

The given data testify to the insufficiently effective activity of the operational subdivisions on counteracting crime, which necessitates the improvement of the mechanism for conducting special operational-search measures. In this regard, tougher requirements for organizational and tactical features of the use of information obtained during their conduct. In particular, one of the promising areas related to crime detection and crime prevention is the introduction and use of DNA databases, which will contribute to exposing persons who have committed criminal offenses and left traces of biological origin. The necessity and possibilities of using DNA accounting in the fight against crime have already been indicated both by Kazakhstan (Khanov, Sihimbaev, Birzhanov \& Birzhanov, 2016:549) and by Russian authors (Volchetskaya, Makarenko, Aminev \& Seitenov, 2018).

These circumstances objectively determine the need for theoretical development and the emergence of substantiated practical recommendations on the use of tools and methods of operational search activities. In this direction, a large amount of work was carried out by Russian scientists: Klyonov D.I. (2005); Zakharysev S.I. (2004a); Elimskiy V.I. (2001); Krashennikov N.I. (2001), Kazakhstan theorists and practitioners also contributed, for example, Lakbaev K.S., Rysmagambetova G.M., Saitbekov A.M., Mukhamedzhanov Y.O. (2017); Nurtaev A.B., Shaimuhanov A.D., Manapov, K.B. (2018); Elimskiy V.I. (2001); Nurgaliyev B.M., Syzdyk B.K., Boretsky A.V. (2016); Shaimuhanov A.D. (2018).

Thus, the importance of the study of the use of operational-search measures in the criminal process, the requirements for the admissibility of the results, gave impetus for the in-depth study of the scientific features of the conduct and legal regulation of operational-search measures. As a result, a proposal was made to introduce into the criminal proceedings of the institute of secret investigative actions, as we have previously indicated (Madiev, 2015:49).

\section{RESULTS}

M.Ch. Kogamov was one of the first Kazakhstani scientists, who gave an explanation on the regulation of the secret investigative actions in the commentary to 
the new version of the Criminal Procedure Code. By introducing this institution, the former "behind seven seals" operational investigative activity becomes an organic part of the investigation and proof of the circumstances of the criminal offense committed. Kogamov M.Ch. explained the key norms of secret investigative actions, the conditions and grounds for their conduct, questions of research and evaluation of information obtained as a result of an unofficial investigative action, and its use as evidence in criminal cases (Kogamov, 2015:8-9).

Meanwhile, there is a need to distinguish the secret operational-search activity from the secret investigative procedure. In addition, an ambiguous attitude was expressed by Kazakhstani scientists on the issue of introducing secret investigative actions in the criminal proceedings of the Republic of Kazakhstan (Ginzburg, 2013; Orumbaev, 2015:76; Khanov, 2017). Despite the fact that Professor A.N. Akhpanov and Associate Professor A.L. Khan has already tried to make such a distinction (2018), we will designate our approach on this issue.

First, it is necessary to determine what an operational-search activity is, what it consists of, what is regulated and what it is intended for.

The Law of the Republic of Kazakhstan "On operational investigative activities" was signed by the President of the Republic of Kazakhstan on September 15,1994 . This law was the first regulatory and legal act of Kazakhstan, which regulates in the open press many aspects of a specific operational-search activity, conducted mainly behind the scenes. This event corresponds to the Constitutional principle of building a legal, democratic state.

The law defines operational investigative activities; exhaustively lists the state bodies authorized to carry it out, formulates the basic rights and duties, defines measures for the legal and social protection of officials of these bodies, and also contains a number of other important provisions (Ginsburg, Grigor'ev \& Aleskovskiy, 1999:3).

Article 1 of the Law of the Republic of Kazakhstan "On operational investigative activities" provides the following definition of operational investigative activity: Operational investigative activity (hereinafter referred to as OIA) is a scientifically based system of public and secret operational investigative, organizational and managerial activities carried out in accordance with the Constitution Of the Republic of Kazakhstan, this Law, and other regulatory and legal acts of the Republic of Kazakhstan by the bodies carrying out operational investigative activities in order to protect life, health, rights, freedoms and legitimate interests of a person and a citizen, property, ensuring the security of society and the state from criminal encroachments.

The definition emphasizes the legal and scientific validity of the system of public and secret operativesearch, organizational and managerial measures, limits the range of subjects of the OIA, specifies the goals.

In accordance with this standard, operational search activity is, above all, a system of activities carried out by specially authorized state bodies listed in the law and authorized to conduct them (Sysalov, 2002:8).

It follows that the legislator indicated that the operational-search activity is carried out by authorized bodies in accordance with the Constitution of the Republic of Kazakhstan, the Law "On OperationalSearch Activity" and other legal acts of the Republic of Kazakhstan. At the same time, it is possible to consider the operational-search measure as the main part of the operational-search activity, through which they are carried out. If you follow this wording, then the word "by" in Russian means "with the help of something", "using something" (Ozhegov \& Shvedova, 1999:586).

So, in particular, the court uses the specific results of operational-search measures, and not the totality of all the tasks and objectives of the science of operational-search activity. According to S.I. Zakhartsev, most of whose works are devoted to the issue under consideration, such an understanding of the operational-search activity does not correspond to its true, actual state. Since the operational-search activity involves a broader understanding (Zakharysev, 2004b:8-10).

In general, we share this position and believe that the Law "On Operational-Search Activity" includes not only the conduct of operational-search activities, but also other actions in the operational-search activity: engaging individuals in confidential assistance, setting up enterprises, maintaining specific financial activities, etc. that is, these actions are parts of the operationalsearch activity.

Since the operational-search measures are included in the structure of the operational-search activity, in accordance with the goals and objectives of this activity, they are regulated by the operational-search legislation. In this regard, the principles, tasks, legal 
regulation of operational-search activities fully extend to operational-search measures.

At present, the development of the science of operational-search activity is determined by the development of each of the sections of this science, these theories are private with respect to the general theory of operational-search activity. At the same time, the fundamentals must be laid in each of its parts, regardless of changes or additions to the current legislation.

According to D.A. Kerimov: the separation of sectoral legal sciences from the philosophy of law is fraught with the danger of reproducing only traditional problems that have long been resolved and known, and distracting from new problems constantly posed by the life of society (Kerimov, 2001:82).

Since the theory is a set of generalized provisions that form science, the systematization of knowledge gives a complete reflection of the essential laws and relationships in a certain area of reality (Salnikov, Fedorov, Khon \& Dzhegutanov, 1999:295).

The theory of operational-search activities is private in relation to the general (unified) theory of operationalsearch activity, which forms the relevant science. At the same time, many scientists believe that a unified theory of operational search activities has not yet been formed, however, there is a lot of scientific and practical experience for the cognition and empirical formulation of this theory, therefore there is a consistent process of changing one state to another, more perfect (Ozhegov \& Shvedova, 1999:664).

In this regard, it seems appropriate to consider the essence of operational search activities (hereinafter OSA).

According to the Russian authors V.M., Meshkov, V.L. Popova (1999:18): operational-search measures are an integral structural element of operational-search activity, consisting of a system of interrelated actions aimed at solving specific tactical tasks.

According to V.I. Grigorieva and V.S. Pletnev operational search activities, it is:

1) the actions of the subjects of the OIA within their competence, aimed at solving their tasks;

2) a system of methods for obtaining and implementing operatively significant information, as well as methods of organizational and tactical nature;

3) the actions of the subjects of the OIA, their structural subdivisions, based on the use of operational-search forces, means, methods and techniques, carried out by officials specially authorized to do so.

At the same time, as indicated features of OSA the indicated authors single out: the presence of a tactical target; relative small number of simultaneously used forces and means; insignificant scale of operationalsearch actions, limited to a specific section of the OIA; relative short duration in time; the achievement of the result, which usually has a local value (Grigor'ev \& Pletnev, 2007:73).

Based on the definitions that have been voiced, it can be concluded that operational search activities are specific actions of the bodies carrying out operational search activities within their competence aimed at solving the tasks facing these bodies, provided for by Article 11 of the Law on Operational Search ".

It is possible to identify the main elements that characterize the essence of the operational search activities.

1. Operational-search measures are a system of intelligence (search) measures based on legislative and subordinate regulatory acts, carried out mainly by special means and methods in order to prevent and solve crimes and search for hiding criminals.

2. When carrying out operational-search activities, scientific and technical means and methods can be widely used to detect, fix, seize, research information about an impending, committed or committed crime.

3. Types and tactics of the implementation of operational-search measures are scientifically grounded and practically tested.

4. No one, except for the entities specified in the legislation, shall have the right to conduct operational search activities. No other organizations or persons have the right to carry out this activity.

At the same time, it is necessary to keep in mind that operational-search measures are tactically and 
psychologically subtle and sharp weapons, with the help of which the subject of operational-search activities penetrates the criminal intent and makes the secret explicit in order to prevent or uncover crime (Ginsburg, Grigor'ev, Aleksovskiy, 1999:40-41).

Thus, operational-search measures are the main form of operational-search activity. In turn, from a set of operational-search actions, we can distinguish a system of special operational-search measures.

In accordance with paragraph 3 of Article 11 special operational-search activities are:

1) unspoken audio and/or video monitoring of a person or place;

2) the secret control, interception and removal of information transmitted over the networks of electrical (telecommunications) communications;

3) secretly receiving information about connections between subscribers and (or) subscriber devices;

4) the secret removal of information from computers, servers and other devices designed to collect, process, accumulate and store information;

5) tacit control of postal and other items;

6) unspoken penetration and/or inspection of the site.

The organization and tactics of conducting special operational-search measures are determined by the regulatory legal acts of the first heads of the bodies carrying out operational-search activities, in coordination with the General Prosecutor of the Republic of Kazakhstan.

Along with the concept of "special operationalsearch measures", in the theory of OIA, such a form as operational-search operation is used.

Operational search operation is a set of interrelated and coordinated according to the purpose, place and time of operational search activities and individual actions carried out according to a common plan, led from a single center, aimed at solving the complex task of the OIA. Signs of a search operation are: a strategic goal for example, paralyzing the criminal activities of an international terrorist organization or an important tactical goal for example, controlling the drug trafficking channel (Khanov, Bakishev, Fetkulov \& Nurpeisova, 2017:624).

As a rule, a relatively long-term nature (in some cases, operations may be short-term, for example, an operation to capture a criminal with a red-handed one, an operation to free hostages); the use of substantial forces of funds, often a number of bodies and divisions; The management structure specially created for the period of the operation is the center that organizes, controls, and coordinates all activities of the operation (Sysalov, 2002:91).

The fact that OSA is an intrusive method of gathering information determines their differentiation into various categories. Since OSA differ in certain features, the Law of the Republic of Kazakhstan "On operational investigative activities" provides for a distinction between general and special. Meanwhile, in the legislative acts of the CIS countries and the Baltic States regulating the operational-search activity, the distinction between operational-search measures is not always applied.

\section{DISCUSSION}

As is well known, the study of operational-search measures as part of the general theories of operational-search activity cannot do without a comparative analysis with foreign experience in the introduction and use of organizational and tactical features of conducting special operational-search measures in the fight against crime in investigating criminal cases. In this regard, we consider the legislation of the Russian Federation, the Republics of Belarus and Latvia, in relation to the issue under study.

As well as in Kazakhstan, in the Russian Federation, on August 12, 1995, the Federal Law "On Operational-Search Activity" was adopted. In accordance with Article 6 of this law, there are 15 types of measures related to operational search activities, but unlike Kazakhstan there is no differentiation into special and general ones.

At the same time, an attempt to distinguish OSA into different types, taking into account their importance in accomplishing the tasks of the OIA in the Russian Federation, was made in the draft Federal Law "On the Fight against Organized Crime", which was never adopted.

In this draft law it was supposed to establish a rule according to which special operational-search 
measures are carried out only when it is otherwise impossible or difficult to detect, prevent, suppress and solve crimes (Goryainov, Kvasha \& Surkov, 1997:199).

The basis of the operational-search legislation of the Russian Federation consists of:

1) The Law of the Russian Federation "On operational investigative activities";

2) Legislative acts that determine the regulatory status of the bodies implementing the OIA:

- certain norms of the Law of the Russian Federation "On Internal Affairs Bodies";

- separate norms of the Law of the Russian Federation "On National Security Bodies".

3) Subordinate regulatory acts, including decrees of the President of the Russian Federation, decrees and orders of the Government of the Russian Federation both directly on OIA issues and regulating certain legal relations in the field of OIA, acts of the Prosecutor General's Office of the Russian Federation regarding OIA, as well as interdepartmental and departmental regulations of federal executive bodies regulating certain legal relations in the sphere of OIA (Goryainov \& Ovchinskiy, 2018:42).

The Law of the Russian Federation "On the operational-search activity" is specific in terms of the tasks of the OIA, since the lawmaker does not only include the main ones among them:

detection, prevention, suppression and detection of crimes, as well as the identification and identification of persons preparing them, committing or committing them (as in the Republic of Kazakhstan);

- the implementation of the search for persons hiding from the bodies of inquiry, investigation and court, evading criminal punishment, as well as the search for the missing;

- obtaining information about events or actions (inaction) that threaten the state, military, economic or environmental security of the Russian Federation;

- the establishment of property subject to confiscation.
The provision of these tasks is intended to provide operational-search measures, the catalog of which is similar to the list of special operational-search measures by the Law of the Republic of Kazakhstan on the OIA. Along with this feature of the list of OSA, firstly, that similar OSA are described in more detail, there are no distinctions on the features, on special and general.

Secondly, to provide separate OSA, a slightly different terminology is used than in the Law of the Republic of Kazakhstan on OIA, in particular:

- inspection of premises, buildings, structures, areas of the terrain and vehicles.

- $\quad$ control of mail, telegraph and other messages.

- $\quad$ wiretapping.

- removal of information from technical communication channels.

- observation.

The procedure for conducting special OSA that limit constitutional rights and freedoms of a person and a citizen by the legislator in the Russian Federation is stipulated by a number of conditions (as in the Republic of Kazakhstan), Article 8 of the Law on the OIA of the Russian Federation.

Operational-search measures affecting the secrets of correspondence, telephone conversations, postal, telegraphic and other messages transmitted through electrical and postal networks, as well as the right to privacy of the home, protected by law, and subject to the availability of information:

1. About the signs of a prepared committed or committed illegal act, according to which the preliminary investigation is obligatory.

2. On persons preparing, committing or committing a wrongful act, according to which the preliminary investigation is obligatory.

3. About events or actions (inaction) that threaten the state, military, economic or environmental security of the Russian Federation.

Comparing the OSA catalogs provided for by the Law of the Russian Federation and the Law of the Republic of Kazakhstan on the OIA, one can see that they basically coincide, we will conduct a comparative analysis of the OSA: 
1. Observation is the OSA, which consists in the secret visual, electronic or integrated monitoring of the actions, movements and conversations of specific individuals, as well as events and the situation in the crime scene in order to obtain and record information about signs of criminal activity, possible accomplices, places storage of crime instruments and stolen property.

Electronic surveillance, based on the use of special technical means of monitoring the behavior and actions of the suspect in premises and vehicles, is conducted by employees of special operational and technical units of law enforcement. A variation of electronic surveillance is the unofficial audio and video recording of verbal conversations by suspects without the use of communication tools. The equipment of secret audio and video recordings can be used both with the consent of one of the participants in the observed events, and secretly from all the persons participating in them.

2. Removal of information from technical communication channels is the OSA consisting in receiving (intercepting), converting the fixation with the help of special technical means of textual, graphical and other information transmitted via any technical communication channels.

This OSA may include scanning of a technical channel, radio interception, copying and other actions with subsequent recording of information on magnetic, text (paper), electronic media.

The technical channels include telecommunication channels used to transmit and receive signs, signals, written text, images, sounds with the help of technical means over a wired, radio and other electromagnetic system.

For the conducting of the considered OSA, employees of enterprises, organizations whose technical channels and means of communication are used to remove information may be involved. It is carried out independently by specialized operational units using special technologies, technical and hardware (Law of the Republic of Belarus "On operational investigative activities" $307-3$ of July 15, 2015: 108).

3. Listening to telephone conversations as receiving and recording using technical means of acoustic information transmitted via telephone lines or unilateral messages is carried out in order to detect information about the criminal activity of the person being studied, to identify his connections and to obtain other information conducive to solving specific tasks of the OIA.

Listening to telephone conversations involves tacit monitoring of voice communication through wired and wireless telephony by connecting stationary equipment to telecom operators to either a wired communication line or scanning the telephone signal of the listening object.

Listening to telephone conversations involves monitoring the conversations of both subscribers, and by connecting or scanning a radio channel. Listening (hearing control) of a telephone conversation of only one of the subscribers, including those using technical means, without intrusion (connection) in the communication network does not form the considered OSA, but is a type of electronic surveillance (Goryainov, Kvasha \& Surkov, 1997:106).

4. Control of mail, telegraph and other messages is the OSA, which consists in obtaining information about the signs of criminal activity of the inspected person through the secret opening and viewing (perusal) of his mail, telegraph and other messages. In the Republic of Kazakhstan, a similar event, the unofficial control of postal and other items, differs only with a different terminology, in addition to the above, the secret control of radiograms and wrappers is used.

Other messages may include, for example, information whose presentation and transmission is allowed together with a postal transfer, as well as messages received from the sender on paper or magnetic media for transmission by electronic means and delivered to the addressee in conventional or electronic form (sending e-mail). Such messages in the usual physical form are presented to the addressee in a sealed form as written correspondence (Goryainov, Kvasha \& Surkov, 1997:103).

5. Inspection of premises, buildings, structures, areas of terrain and vehicles - this is a OSA, consisting of a non-procedural examination of objects in order to detect traces of criminal activity, instruments of a crime, wanted criminals, as well as obtaining other information necessary to solve specific tactical tasks (Goryainov, Kvasha \& Surkov, 1997:100). 
The private investigation in the Russian Federation, as well as in the Republic of Kazakhstan, is conducted in secret from the owners of the inspected objects and interested persons, and it has a special procedure envisaged by departmental regulatory acts. Such a survey is carried out with the use of operationaltechnical means of bodies carrying out OIA, with the participation of the initiators of the event.

The Law of the Republic of Belarus on OIA was adopted on July 15, 2015, it determines the content of operational-search activity, regulates the relations of the parties during its implementation and establishes a system of legal guarantees for the use of operationalsearch measures based on the priority of universal human values, the implementation of constitutional rights and freedoms of citizens.

Specificity in comparison with a similar law of the Republic of Kazakhstan is manifested primarily in the definition of the essence of the OIA. So in Article 1 of the Law of the Republic of Belarus "On OperationalSearch Activity", it is recognized as a state-legal means of protecting the rights, freedoms, interests, property of citizens, society, and the state from criminal encroachment. It is carried out publicly and unofficially authorized by this law by government agencies and operational units in order to prevent and solve crimes by conducting operational search activities.

The peculiarities of their authority are that the OIA in full and with the use of the entire catalog of the OSA is carried out by:

- bodies of internal affairs of the Republic of Belarus;

- $\quad$ state security agencies of the Republic of Belarus;

Operational units of the border troops under the Council of Ministers of the Republic of Belarus.

These bodies have the right to apply: citizens survey; inquiry; collecting samples for comparative studies; test purchase; study of objects and documents; observation; personal identification; inspection of premises, buildings, structures, areas of terrain, vehicles; auditory control; control of mail, telegraph and other messages; wiretapping; removal of information from technical communication channels; operational implementation; controlled delivery; operational experiment (Law of the Republic of Belarus "On operational investigative activities" 307-3 of July 15, 2015).
In the Republic of Belarus, the Law "On Operational-Search Activity", Article 11 provides for 15 operational-search measures. Without classifying them according to any signs, the law distinguishes 5 special operational-search measures.

1. Auditory control - receiving and fixing acoustic information in rooms, structures, vehicles and on the ground to solve problems of operationalsearch activity.

It should be borne in mind that the possibility of the use of various technical means by the employees of the bodies carrying out the OIA during various operational activities is not clearly specified in the law. Operational employees have the right to use "video and audio recording, film and photography, as well as other technical and other means that do not harm human health and the environment". There is no provision for obtaining a sanction for their use. From this it follows that the use or non-use of technical means in the process of OIA is the prerogative of the operative worker and for this reason the legislator has granted him the right to independently determine the procedure and conditions for the use of various scientific and technical means when conducting OIA, without asking for anyone's permission.

Auditory control in the Republic of Belarus differs from a special event under the Law "On OperationalSearch Activity" of the Republic of Kazakhstan, secret audio - and (or) video monitoring of a person or place, only by the method, method and location of a special event.

The tacit audio and/or video monitoring of a person or place, in accordance with the law "On operational investigative activities" of the Republic of Kazakhstan, as well as the auditory control in the Republic of Belarus, from secret recording a conversation on a dictaphone, when communicating directly with an interlocutor, recorded at a distance, for which the technical means are used, either installed at the location of the interlocutors, or producing a remote fixation of the conversation, being at some distance from the source thief, for example using a directional microphone. In any case, the person exercising auditory control is not located at the place where the conversation is being listened to and records it at a distance, while being in another place ("at a temporary control point"). Since for these purposes special technical means are used, which are intended for secretly obtaining information, for this reason, only 
employees of operational units performing the OIA can perform auditory monitoring.

2. Removal of information from technical communication channels - receiving, transforming and fixing, using technical means, various types of signals transmitted via any technical communication channels, for solving operationalsearch activity tasks, is provided for by paragraph 12 of Art. 2 of the Law "On Operational Search Activity" of the Republic of Belarus.

In the Republic of Belarus, as in the Russian Federation, the removal of information from technical communication channels is combined into one, in fact, two special operational search activities - tacit control, interception and removal of information transmitted via electrical (telecommunication) communication networks and tacit removal of information from computers servers and other devices designed for the collection, processing, accumulation and storage of information provided for by paragraph 3 of Art. 11 of the Law "On Operational Search Activity" of the Republic of Kazakhstan. In our opinion, the inclusion of two OSA into one special event greatly simplifies the procedure for conducting covert investigations.

3. Listening to telephone conversations - listening and recording in the form of sound recordings on magnetic and other carriers of acoustic information transmitted over electric telephone networks during telephone conversations. In accordance with paragraph 11 of Art. 2 of the Law "On Operational-Search Activity" of the Republic of Belarus, is intended for solving problems of operational-search activity, differs from the Kazakhstan secret event only by name.

In contrast to the Russian and Belarusian legislators in the Republic of Kazakhstan, paragraph 20 of Art. 1 of the Law "On Operational-Search Activity" provides for secretly obtaining information about connections between subscribers and (or) subscriber devices. At its core, it is to obtain information about the date, time, duration of connections between subscribers and (or) subscriber devices (user equipment) as part of listening to the conversation or, along with or without listening, to establish the location of the subscriber.

4. Monitoring of mail, telegraph and other messages - viewing mail, telegraph and other messages in order to find out information about the criminal activity of the inspected person and to receive other information in order to solve the tasks of the operational-search activity (paragraph 10 of Article 2 of the Law operational search activity ").

The control of mailings, telegraph and other communications under the Law of the Republic of Belarus differs from a special event by the tacit control of postal and other communications provided for by the Law on Operational Search Activities of the Republic of Kazakhstan, only in content and purpose of the special event.

5. Inspection of premises, buildings, structures, areas of terrain and vehicles - inspection of the said objects in order to possibly detect signs of criminal activity, as well as events or actions that pose a threat to the national security of states (paragraph 8 of Article 2 of the Law activities »RB).

This event, envisaged in the Republic of Belarus, differs from a special event: the unofficial penetration and (or) survey of the site, regulated by paragraph 13 of Art. 1 of the Law "On Operational-Search Activity" of the Republic of Kazakhstan by the fact that in the Republic of Belarus in the survey of premises, structures, areas and vehicles is carried out both publicly and privately, with the possibility of seizure of detected objects in exceptional cases (Educational and methodical complex on the program of the special course OSA: 25-26). In the Republic of Kazakhstan, these activities are carried out only behind the scenes, without the possibility of removing any items found.

Thus, the legislation regulating the conduct of special operational-search activities in Kazakhstan, the Russian Federation and Belarus has many similarities; the features are manifested only in the number, name, and partly in the content of special operational-search activities, while their essence is manifested equally.

For comparison, we consider the Law "On Operational Activities" of the Republic of Lithuania of December 5,2002 . It is dedicated to the regulation of the OIA of law enforcement agencies, special services and, in part, private investigation.

This legislative act, the most succinctly setting out the main directions of operational activities. It regulates the provision of powers for the use of technical means and operational methods of penetrating character in the collection of information in the field of infrastructure and state crimes and criminal offenses. 
Comparing the catalogs of operational-search measures provided for by the Law of the Republic of Kazakhstan and the Law of the Republic of Lithuania "On Operational Activities", one can see that they mostly coincide. In addition, in Article 3 of the Law of the Republic of Lithuania, determined the essence of the OSA. Consider only those activities that fall under the special OSA under the law of the Republic of Kazakhstan "On operational investigative activities":

1. Operational inspection is a method of operational activity in which information comes in open form, in encrypted form or by secretly inspecting objects, documents, premises, vehicles, terrain, persons and other objects, as in the Republic of Kazakhstan, tacit penetration and ( or) a site survey carried out by similar methods, only the objects of study differ.

2. Electronic intelligence is a method of operational activities in which information is obtained by electronic technical means. With regard to the catalog of special OSA of the Republic of Kazakhstan, it can be stated that electronic intelligence includes three events at once, the unofficial audio- and/or video control of a person or place; tacit control, interception and removal of information transmitted over electrical (telecommunication) communication networks; the secret removal of information from computers, servers and other devices designed to collect, process, accumulate and store information.

3. Secret control over mailings - provides for the interception and verification of mail and other correspondence sent, advertising mailings, mailings and other items. The specifics of this event are manifested only in terminology system.

The peculiarity of the regulation of the OSA in the considered legislation is manifested in the fact that separate articles are devoted to independent articles, while others are not.

For example, Article 10, along with mailings, postal orders and their documents, regulates the use of technical equipment in a special order and receiving information from telecommunication operators and telecommunications service providers.

Article 11 regulates the secret access to residential and non-residential premises, vehicles, as well as their inspection, temporary seizure and inspection of documents, taking samples of materials, raw materials and products, and other objects for research without announcing their seizure.

In accordance with the legislation of Latvia, a whole range of methods of OIA is combined, by including two or more special events in one OSA. According to the Law of the Republic of Kazakhstan "On operational investigative activities", each event is carried out independently and only with the approval of the supervisory authority.

In the study, we came to the conclusion that operational search activities in different countries have their own characteristics, by subjects entitled to conduct them, terms, conditions, grounds, concept, essence, assessment of the results of operational search activities, authorization of OSA in the Russian Federation by a court decision, in the Republic of Belarus, Lithuania and Kazakhstan with the sanction of the prosecutor's office. However, when studying the legal regulation of operational-search measures of Western countries, it is obvious that not all of them have the possibility of restricting rights, the court or the prosecutor's office is vested. For example, in the UK, the Secretary of State of this state is permitted to hold these events, in Germany the minister appointed by the Chancellor is authorized to listen in on telephones in Germany, and the Prime Minister has two of his specially authorized assistants in France (Vdovin, 2000).

\section{CONCLUSION}

Thus, a comparative analysis with foreign experience in the regulation of operational search activities shows the features of openly published legislative and other legal acts regarding various procedures for collecting and processing criminal information, as well as its use in the fight against crime.

The peculiarity of the Law of the Republic of Kazakhstan "On operative-search activity" from similar laws of foreign countries is the corresponding distinction of OSA into general and special, in the opinion of the legislator, these events have certain features to be reflected in legislative acts on operational-search activity.

The catalog of operational-search measures is basically similar to the list of special operational-search measures provided for by the law of the Republic of Kazakhstan "On operational-search activity"; only a slightly different terminology is used. 
In the Republic of Kazakhstan there are two special operational-search measures:

1) secret monitoring, interception and removal of information transmitted via electrical (telecommunication) communication networks;

2) the secret removal of information from computers, servers and other devices intended for collecting, processing, storing and storing information is combined into one event - the removal of information from technical communication channels provided for by the legislation of the Russian Federation and the Republic of Belarus.

In clarifying the above, in our opinion, the inclusion of two OSAs into one special event greatly simplifies the procedure for conducting covert investigations, obtaining one sanction for a complex of special investigative measures when removing any information from the technical channels of communication, such as voice, electronic, paper, text, magnetic media.

Appearances and development of operationalsearch measures historically existed always, through the accumulation of scientific knowledge and the development of scientific and technological progress, methods of operational work were improved and supplemented. To ensure the reliability of the results obtained, scientific and technical means are being actively introduced, mechanisms and methods for recording operational information are being improved, and well-grounded recommendations for conducting operational search activities are being developed.

\section{REFERENCES}

Akhpanov, A.N. \& Khan, A.L. (2018). Theory and practice of differentiation of operational search activities and secret investigative actions. Vestnik Instituta zakonodatel'stva RK, no 3(52). 45-54.

Analytical information: Information on criminal offenses. Committee on Legal Statistics and Special Records of the Prosecutor General of the Republic of Kazakhstan Committee on Legal Statistics and Special Records of the Prosecutor General of the Republic of Kazakhstan. Retrieved from http://pravstat.prokuror.gov.kz/rus/o-kpsisu/deyatelnostkomiteta/analiticheskaya-informaciya

Educational and methodical complex on the program of the special course OSA. Gomel: Gomel'skiy gosudarstvennyy universitet imeni Frantsiska Skoriny.

Elimskiy, V.I. (2001). Methodological Principles of operatively-search activity theory. Moscow: Izdatel Shumilova I.I.

Federal Law "On Operational-Search Activity" dated August 12, 1995 $N$ 144-FL. Retrieved from http://www.consultant.ru/ document/cons_doc_LAW_7519
Ginsburg, A.Ya., Grigor'ev, V.I. \& Aleskovskiy, S.U. (1999). Fundamentals of operational and investigative activities. Almaty: YOO "Ayan Edet".

Ginzburg, A.Ya. (2013). About the so-called "secret investigative actions". Retrieved from http://www.zakon.kz/4568011-o-taknazyvaemykh-neglasnykh.html

Goryainov, K.K. \& Ovchinskiy, V.S. (2018). Theory of operational investigative activities. Moscow: INFRA-M.

Goryainov, K.K., Kvasha, U.F. \& Surkov, K.V. (1997). Commentary on the Federal Law "On Operational-Search Activity". Moscow: Novyi urist

Grigor'ev, V.I. \& Pletnev, V.S. (2007). Concepts and terms concepts and terms for operational-search and administrative activities: an explanatory dictionary. Commentary on the Criminal Procedure Code of the Republic of Kazakhstan 2014. Vol 2. Almaty: Jeti Jarğı.

Kaidarov, R. \& Kul'baeva, A. (2016). Abdrakhman Aytiev - life for the people. Almaty: Megalis.

Kerimov, D.A. (2001). Methodology of law (subject, functions, problems of legal philosophies). Moscow: Avanta+.

Khanov, T.A. (2017). Institute of covert investigative actions: problems of theory and practice. Proceedings from International Scientific Practical Conference: Theoretical and practical aspects of the development of legal science: current problems and solutions. Karaganda: KEUK. 20-22.

Khanov, T.A., Bakishev, K.A., Fetkulov, A.H., Nurpeisova, A.K. (2017) General characteristics of legislative novels in the sphere of counteracting drug trafficking in the Republic of Kazakhstan. Russian journal of criminology, no 11(3), 623632.

https://doi.org/10.17150/2500-4255.2017.11(3).623-632

Khanov, T.A., Sihimbaev, M.R., Birzhanov, B.K. \& Birzhanov, K.K. (2016). Genomic registration as a universal identifier of the individual in the system of crime prevention measures: research and implementation prospects. Russian journal of criminology, no 3(10). 544-553. https://doi.org/10.17150/2500-4255.2016.10(3).544-553

Klyonov, D.I. (2005). The procedural order of the use of the results of operational investigative activities in proving the pre-trial stages of criminal proceedings. Izhevsk.

Kogamov, M.Ch. (2015). Commentary on the Criminal Procedure Code of the Republic of Kazakhstan 2014. Vol 2. Almaty: Jeti Jarğı.

Krashennikov, N.I. (2001). Obtaining operational procedural information about crimes and its use in operational judicial and investigative practice. St. Petersburg: Ekstraprint.

Lakbaev, K.S., Rysmagambetova, G.M., Saitbekov, A.M. \& Mukhamedzhanov, Y.O. (2017). Investigative measures in prejudicial inquiry: The concept, content and the basics of law enforcement. Man in India, no 20(97).373-380.

Law of the Republic of Belarus "On operational investigative activities" $307-3$ of July 15, 2015. Retrieved from https://online.zakon.kz/document/?doc_id=39712070

Law of the Republic of Kazakhstan "On operational investigative activities" of September 15, 1994 No. 154-XIII. Retrieved from http://adilet.zan.kz/rus/docs/Z940004000

Law of the Republic of Lithuania "On Operational Activities" of June 20, 2002 No. IX-965. Retrieved from https://www.legislationline.org/ru/documents/action/popup/id/ 14922

Madiev, R.A. (2015). On the issue of the definition of "secret investigative actions" under the new Criminal Procedure Code of the Republic of Kazakhstan. Sibirskiye ugolovnoprotsessual'nyye i kriminalisticheskiye chteniya, no 1(7). 4150.

Meshkov, V.M. \& Popov, V.L. (1999). Operational search tactics and features of the legalization of the information obtained during the investigation. Moscow: Schit-M. 
Nurgaliyev, B.M., Syzdyk, B.K. \& Boretsky, A.V. (2016). The realities and patterns of crime in Kazakhstan: some approaches to its analysis. The Social Sciences (Pakistan). Vol 11. № 6. 10691078.

Nurtaev, A.B., Shaimuhanov, A.D. \& Manapov, K.B. (2018). Some peculiarities of implementation of departmental control over the intelligence activities. Opcion Universidad del Zulia. Vol. 34. № 17.191-205

Orumbaev, N.E. (2015). Secret investigative actions on the new Criminal Procedure Code of Kazakhstan. Vestnik Omskoy yuridicheskoy akademii, no 3(28). 75-77.

Ozhegov, S.I. \& Shvedova, N.U. (1999). Explanatory dictionary of the Russian language. The Russian Academy of Sciences. Institute of Russian Language named after V.V. Vinogradov. $4^{\text {th }}$ ed. Moscow: Azbukovnik.

Salnikov, V.P., Fedorov, V.P., Khon, G.N. \& Dzhegutanov, B.K. (1999). Philosophy. St. Petersburg: Sankt-peterburgskiy universitet MVD Rossii.

Shaimuhanov, A.D. (2018). On the issue of legislative regulation of some operational-search measures and secret investigative actions. Aktual'nyye problemy sovremennosti, no 2(20). 6-12.

Suetin, A. (2018).Experts provide search. Retrieved from http://ibirzha.kz/rozysk-vedut-znatoki
Sysalov, M.P. (2002). Operational search activity in the Republic of Kazakhstan. Almaty: Deneker.

Umnov, M.I. (2000). Worldwide Spying History. Moscow: Olimp; OOO Firma "izdatelstvo AST".

Vdovin, U.I. (2000). Protection of the rights of citizens in the implementation of a system of operational-search measures in communication networks. St. Petersburg: Lik. Retrieved from https://www.coast.ru/referats/librery1/editions/lic/ ch19.htm

Vinnichenko, N.A., Zakharysev, S.I. \& Rohlin, V.I. (2004). Legal regulation of the use of operational investigative activities in criminal proceedings. St. Petersburg University of the Ministry of Internal Affairs of Russia, Academy of Law, Economics and Life Safety. St. Petersburg: Fond "Universitet".

Volchetskaya, T.S., Makarenko, I.A., Aminev, F.G. \& Seitenov, K.K. (2018).Genomic registration issues in Eurasia and ways of their solution. Journal of the Siberian Federal University. Series: Humanities, no 12(11). 2078-2088. https://doi.org/10.17516/1997-1370-0374

Zakharysev, S.I (2004b). Operational-search activities. General provisions. St. Petersburg: Uridicheskiy tsentr-Press.

Zakharysev, S.I. (2004a). Theory and legal regulation of operational search activities. St. Petersburg.

\section{DOI: https://doi.org/10.6000/1929-4409.2021.10.20}

(C) 2021 Madiev et al.; Licensee Lifescience Global.

This is an open access article licensed under the terms of the Creative Commons Attribution Non-Commercial License (http://creativecommons.org/licenses/by-nc/3.0/) which permits unrestricted, non-commercial use, distribution and reproduction in any medium, provided the work is properly cited. 